\title{
A critical analysis of the meaning of the term 'income' in Sections 7(2) to 7(8) of the Income Tax Act No. 58 of 1962
}

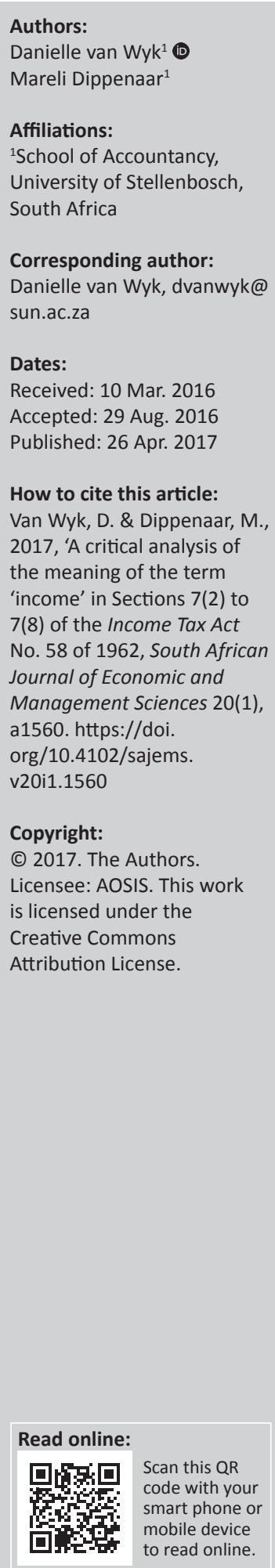

Background: Section 7 of the Income Tax Act 58 of 1962 (the Act) was introduced as an antiavoidance measure to prevent tax avoidance by means of a donation, settlement or other disposition in various types of schemes. In terms of this section, in certain circumstances, 'income' is deemed to be income received by or accrued to a taxpayer. Despite the fact that the term 'income' has been used in Section 7 from the time that it was first introduced into the Act and the fact that it is defined in section 1 of the Act, there still remains uncertainty regarding the intention of the legislature and the actual meaning of the term in terms of Section 7.

Aim: The objective of the study is to understand whether the term 'income', as used in Sections $7(2)$ to 7(8) of the Act, is used in its defined sense or if it should be ascribed a different meaning.

Setting: This article examines existing literature in a South African income tax environment.

Method: A non-empirical study of existing literature was conducted by performing a historical analysis within a South African context. A doctrinal research approach was followed.

Results: Possible interpretations determined include 'income' as defined in section 1 of the Act, namely 'gross income' (also defined) less exempt income, 'gross income', profits and gains or 'taxable income' (i.e. 'income' less allowable expenditure, deductions and losses) and 'gross income' less related deductible expenses and losses.

Conclusion: It was found that the meaning of 'income', for purposes of Sections 7(2) to 7(8), remains an uncertainty, and it is recommended that the wording of Section 7 be amended to reflect the intended meaning thereof.

\section{Introduction and background}

Sections 7(2) to 7(8) of the Income Tax Act 58 of 1962 (the Act) were introduced into the legislation as an anti-avoidance measure to prevent tax avoidance by means of a donation, settlement or other disposition by a taxpayer, to or in favour of another, in various types of schemes. In terms of these provisions, a person other than the person who is entitled to the income or who receives the income is deemed to be taxable on certain 'income'. Although the Income Tax Act 28 of 1914 (1914 Act) contained a section that is equivalent to the current Section 7(1) deemed accrual provision and a section that is the predecessor of the current Section 7(2), the equivalent of the current Sections 7(3) to 7(8) was only added much later: As the years went by, more tax avoidance schemes were designed by taxpayers and the legislature attempted to close the loopholes by introducing further anti-avoidance measures. The predecessor of Section 7(3) was added to Income Tax Act 40 of 1925, although no reference was yet made to a donation, settlement or other disposition (those words were only added by Income Tax Act 28 of 1932, resulting in the section closely reflecting the current version of Section 7[3]). Provisions similar to the provisions of the current Sections 7(4) to 7(6) have been part of the South African income tax legislation since 1941 (Republic of South Africa 1941). Section 7(7) was only added in 1983 to counter tax avoidance schemes whereby taxpayers attempted to transfer certain of their income to others, without necessarily surrendering control over the income or over the investments that generate the income (Republic of South Africa 1983). Section 7(8) was only introduced in 2000 (Republic of South Africa 2000), although its provisions were previously covered by the scope of section 9D of the Act. The provisions of section 9D used to provide for the taxation of investment income of controlled foreign entities (presently known as controlled foreign companies) and investment income arising from donations, settlements or other dispositions. However, it was proposed in 2000 that section 9D only deal with the income of controlled foreign entities and that the anti-avoidance provisions relating 
to donations, settlements or other dispositions be included in Section 7, which deals with similar anti-avoidance issues (Republic of South Africa 2000).

Various other changes were made to Section 7 over the years to either cover additional loopholes, to clarify the provisions or to simply make consequential amendments where other legislation, definitions and terminology changed. Section 7(2) was amended numerous times to clarify which persons and what income are covered by its provisions. The section initially only deemed the income of a married woman to be the income of her husband, but this was subsequently amended to deem the income of either spouse (husband or wife) to be the income of the other spouse, in certain circumstances (Republic of South Africa 1991). Other notable amendments to Section 7 include: the addition of Sections $7(2 \mathrm{~B})$ and 7(8)(b) to allow any deduction or allowance relating to the income, in the hands of the spouse (or resident, in the case of Section 7[8]) that is being taxed on the deemed income (Republic of South Africa 1992, 2005a) and the amendment of Section $7(8)$ to refer to 'any amount...which would have constituted income' instead of to 'income' (Republic of South Africa 2004a).

Throughout the current Section 7, with the exception of Section 7(8), the term 'income' is used in the deemed income provisions of this section. Section 7(8) also used to refer to 'income', until it was amended in 2004, as pointed out above. The term 'income' has, in fact, been used in Section 7 from the time it was first introduced into the Act. In addition, the term 'income' is defined in section 1 of the Act and has had the same meaning, namely 'the amount remaining of the gross income...after deducting therefrom any amounts exempt from normal tax...', since 1925 (Republic of South Africa 1925, 1941, 1962). The 1914 Act, which contains the predecessors of the current Section 7(1) and 7(2), also referred to 'income' in those sections, although 'income' had an entirely different meaning back then. There was no distinction between 'gross income' and 'income' in 1914 and 'income' was defined as 'any gains or profits derived by, or accrued to or in favour of...from any source within the Union...'. However, although the term used in Section 7 and its definition in section 1 have remained unchanged from 1925, there still remains uncertainty regarding the intention of the legislature and the actual meaning of the term in terms of Section 7.

\section{Problem statement}

The term 'income' is defined in Section 1 of the Act as 'the amount remaining of the gross income... after deducting therefrom any amounts exempt from normal tax under Part I of Chapter II'. The term 'income' is, however, used in some provisions of the Act, where the meaning thereof could be interpreted to be different to the definition in Section 1 of the Act, such as in the anti-avoidance measures of Section 7. If these sections of the Act are interpreted incorrectly, it can have far-reaching consequences, which might lead to either a loss to the fiscus or unfair tax consequences for the taxpayer.
Various academic writers have identified the lack of guidance from the South African government regarding the meaning of the term 'income', as used in Sections 7(2) to 7(8). These writers have different opinions regarding whether the term means 'income' in the literal (ordinary) sense of the word or if it should be ascribed a different meaning in the context that it is used (Clegg \& Stretch 2007; Davis, Olivier \& Urquhart 1999; De Koker \& Williams 2001; De Swardt et al. 2015; Meyerowitz 2008; Meyerowitz \& Spiro 1995; Olivier 1989).

\section{Research objective, research methodology, scope and value of research}

The objective of the study is to understand whether the term 'income', as used in Sections 7(2) to 7(8) of the Act, is used in its defined sense, namely the amount remaining of the 'gross income' after the deduction of allowable exemptions, or if it should be ascribed a different meaning. A non-empirical study of existing literature was conducted by performing a historical analysis within a South African context. A doctrinal research approach was followed by applying the following steps to solve the specific research problem, as suggested by Hutchinson and Duncan (2012):

- gathering the relevant facts

- identifying the relevant legal issue at hand

- analysing the issue from a legal perspective

- studying relevant background material such as dictionaries, textbooks and journal articles, inter alia

- analysing primary research sources such as case law and legislation

- combining all issues within the context

- reaching a preliminary conclusion.

The research objective was achieved by investigating the following:

- the meaning of the term 'income' as used in Sections 7(2) to $7(8)$ of the Act, by exploring the ordinary definition thereof as well as obtaining an understanding of the different interpretations suggested by various academic writers, as there is no specific guidance available in this regard

- the impact of the different possible interpretations of the term 'income' in Sections 7(2) to 7(8) of the Act on a taxpayer's 'taxable income'.

The study can potentially highlight areas for improvement or, at the very least, for a consideration by the South African Department of National Treasury to clarify the meaning of the term 'income' in Sections 7(2) to 7(8). The study can potentially also assist taxpayers to understand this intended meaning, to correctly apply the provisions thereof in their tax returns. This could prevent possible unfair tax consequences to either taxpayers or the fiscus.

The study commences with a brief summary of all the possible literal (ordinary) meanings of the term 'income' and a discussion of the possible approaches to the interpretation 
of legislation. This is followed by a discussion of the possible interpretations of the term 'income', as suggested by various academic writers, for each of the Sections 7(2) to 7(8), a practical illustration of the impact of each possible interpretation on a taxpayer's taxable income and a conclusion regarding the most likely interpretation intended by the legislature, based on the literature study performed. The study concludes with recommendations for the amendment of the existing wording in Section 7 in order to clarify the legislature's intention regarding the amounts that are deemed to have accrued to a specific person.

\section{The literal (ordinary) meaning of the term 'income'}

The term 'income' can have different meanings, depending on the context in which it is used. The possible literal (ordinary) meaning of the term 'income' is assessed in terms of dictionaries, as well as from an accounting, general business and tax perspective.

The Oxford English Dictionary (2015) defines 'income', inter alia, as profit and proceeds, while the Collins English Dictionary (2015) defines it as 'the amount of monetary or other returns, either earned or unearned, accruing over a given period of time' or 'receipts or revenue'. The Penguin English Dictionary (2015) has a similar definition as the Collins English Dictionary, namely 'money received from work, property, or investment, regularly or over a specified time'. The Chambers Dictionary (2015), on the other hand, defines 'income' as profit or interest from anything, as well as revenue. It therefore seems as if dictionaries define income as representing both a gross and net amount (in other words, after deducting expenditure).

The International Financial Reporting Standards (IFRS Foundation 2015) define 'income' as:

increases in economic benefits during an accounting period in the form of inflows or enhancements of assets or decreases of liabilities which result in an increase in equity, other than those relating to contributions from equity participants. (Appendix A)

This clearly refers to gross amounts, as opposed to net amounts after deductions. From a business perspective, income is generally accepted to represent total receipts, revenue or earnings, in other words, also a gross amount.

The Act, on the other hand, defines the term 'income' in Section 1 as 'gross income' less the exempted income, but before any deductions. According to Clegg and Stretch (2015), 'unless the context otherwise indicates', the meaning attributed to specific words must be those given in the definition sections of the Act. Section 1 of the Act, which defines 'income', contains the words 'unless the context otherwise indicates'. This stipulates that the defined meaning provided will not necessarily apply in all circumstances. Clegg and Stretch (2015) further note that, in establishing whether or not the context indicates otherwise, the whole of the Act must be considered, as other parts of the Act can shed light upon the legislature's intention.

For purposes of this study, the literal (ordinary) meaning of the term 'income' will be interpreted as the defined meaning in Section 1 of the Act, unless the context otherwise indicates.

\section{Interpretation of words used by the legislature}

In this section of the article, the interpretation of words used by the legislature is briefly discussed, to form the basis for the interpretation of the term 'income' as used in Sections 7(2) to 7(8). Clegg and Stretch (2015) note that the interpretation of statutes is frequently a tough task and the rules of interpretation are not applied consistently. They further state that income tax is, in principle, a creature of statute, and the principles of interpretation which apply to statutes, also apply to the interpretation of tax statutes.

According to De Koker and Williams (2015), the meaning of the words used by the legislature is often unclear because of the nature of the language. Reference is made to case law in this regard for guidance on interpretation. Two main approaches of interpretation are applied by the courts when interpreting the law: the literal (textual) approach and the purposive (contextual) approach (De Swardt et al. 2015).

In terms of the literal approach, the interpreter pays attention to the plain language of the provisions of the Act (De Koker \& Williams 2015). The literal approach to the interpretation was described in the judgement of Cape Brandy Syndicate $v$ Inland Revenue Commissioners K.B. (Swarbrick 2015), as follows:

...[I]n a taxing Act one has to look merely at what is clearly said...There is no equity about a tax. There is no presumption as to a tax. Nothing is to be read in, nothing to be implied. One can only look fairly at the language used. (p. 71)

According to Van der Zwan (2015), the literal approach was, however, altered slightly in the case of $R$ Koster $\mathcal{E}$ Son (Pty) Ltd \& Another $v$ Commissioner for Inland Revenue 47 SATC 23. In circumstances where the literal approach gives rise to absurdity, inconsistency, hardship or anomaly, the courts may depart from the ordinary meaning of the word, to the extent that is required to eliminate the absurdity, inconsistency, hardship or anomaly and to give effect to the intention of the legislature by interpreting the word in its context (De Koker \& Williams 2015). If the ordinary wording does not indicate the intention of the legislature, the contra fiscum rule must apply, which means that the text must be given the interpretation that is in favour of the taxpayer (De Koker \& Williams 2015).

The purposive approach determines the purpose of the legislation by taking all the adjacent circumstances and resources into account (De Swardt et al. 2015). In order to give meaning to the fundamental purpose of the statute, the interpreter takes numerous factors into account, including 
the context and political context in which the legislation was approved, the evil which the legislation is intended to forbid and punish and the good which the legislation is intended to indorse (Mota 2012). According to Van der Zwan (2015), the purposive approach essentially entails legislation to be interpreted holistically. He further remarks that wording with several interpretations, and where the purpose of the legislation may not be reflected by some of them, should be seen as preconditions for this interpretation approach and not necessarily ambiguous wording. Ambiguity or uncertainty arises where the meaning of the words used is unclear and can either be regarding individual words or an entire phrase (Clegg \& Stretch 2015).

Sections 39(1) and (2) of the Constitution of the Republic of South Africa, Act 108 of 1996 (the Constitution) state the following:

1. When interpreting the Bill of Rights, a court, tribunal or forum:

(a) must promote the values that underlie an open and democratic society based on human dignity, equality and freedom

(b) must consider international law

(c) may consider foreign law.

2. When interpreting any legislation, and when developing the common law or customary law, every court, tribunal or forum must promote the spirit, purport and objects of the Bill of Rights.

Sections 39(1) and (2) of the Constitution, therefore, indicate that it is vital that the purposive approach be followed when interpreting legislation (De Swardt et al. 2015). Mdumbe (2004) states that the starting point when interpreting legislation remains to read the text. The courts should, nevertheless, also consider the broader context and not limit themselves to the wording of the text.

In 2008, Goldswain performed a study to examine the way that the interpretation of fiscal legislation is approached by our judiciary. The study concluded that the promulgation of the Constitution has been a catalyst for a change in interpretation approaches, from literal to purposive (Goldswain 2008).

Following the aforementioned, the ordinary (literal) meaning of the term 'income' will be referred to, unless it is in conflict with the intention of the legislature and the Bill of Rights. However, seen that Section 1 of the Act, which defines 'income', contains the words 'unless the context otherwise indicates', the defined meaning will not necessarily apply in all circumstances. All circumstances and resources, therefore, need to be considered, to determine the meaning of the term in context of its overall purpose and in context of the Act as a whole. It is therefore submitted that a purposive approach is followed in interpreting the meaning of the term 'income' in Sections 7(2) to 7(8).

In the next section, the article aims to outline the working of Sections 7(2) to 7(8) by investigating the possible meanings of the term 'income' as envisaged in each of these provisions.

\section{Understanding the meaning of 'income' in Sections 7(2) to 7(8) of the Act \\ Section 7(2) of the Act}

Section 7(2)(a) of the Act (Republic of South Africa 1962) reads as follows:

Any income received by or accrued to any person married in or out of community of property (hereinafter referred to as the recipient) shall be deemed for the purposes of this Act to be income accrued to such person's spouse (hereinafter referred to as the donor) if:

(a) such income was derived by the recipient in consequence of a donation, settlement or other disposition made by the donor on or after 20 March 1991 or of a transaction, operation or scheme entered into or carried out by the donor on or after that date, and the sole or main purpose of such donation, settlement or other disposition or of such transaction, operation or scheme was the reduction, postponement or avoidance of the donor's liability for any tax, levy or duty which, but for such donation, settlement, other disposition, transaction, operation or scheme, would have become payable by the donor under this Act or any other Act administered by the Commissioner; or

(b) income was received by or accrued to the recipient:

(i) from any trade carried on by the recipient in partnership or association with the donor or which is in any way connected with any trade carried on by the donor; or

(ii) from the donor or any partnership of which the donor was at the time of such receipt or accrual a member or any private company of which the donor was at such time the sole or main holder of shares or one of the principal holder of shares, and such income represents the whole or any portion of the total income so received by or accrued to the recipient which exceeds the amount of income to which the recipient would reasonably be entitled having regard to the nature of the relevant trade, the extent of the recipient's participation therein, the services rendered by the recipient or any other relevant factor.

Section 7(2A) of the Act (Republic of South Africa 1962) reads as follows:

In the case of spouses who are married in community of property:

(a) any income (other than income derived from the letting of fixed property) which has been derived from the carrying on of any trade shall, if such trade is carried on:

(i) by only one of the spouses, be deemed to have accrued to that spouse; or

(ii) jointly by both spouses, be deemed, subject to the provisions of subsection $(2)(b)$, to have accrued to both spouses in the proportions determined by them in terms of the agreement that regulates their joint trade or, if there is no such agreement, in the proportion to which each spouse would reasonably be entitled having regard to the nature of the relevant trade, the extent of each spouse's participation therein, the services rendered by each spouse or any other relevant factor; and

(b) any income derived from the letting of fixed property and any income derived otherwise than from the carrying on of any trade shall be deemed to have accrued in equal shares to 
both spouses: Provided that any such income which does not fall into the joint estate of the spouses shall be deemed to be income accrued to the spouse who is entitled thereto.

In order to determine the meaning of 'income' in Sections $7(2)$ and 7(2A), reference is made to Commissioner for Inland Revenue $v$ Simpson 4 All SA 460 (A) (the Simpson case), which dealt with the predecessor of the current Section 7(2). In the Simpson case, Judge Watermeyer noted that it was the object of Act 31 of 1941 (1941 Act) to tax a person's profits or gains, in other words, after deducting allowable expenditure incurred in making those profits or gains, and not 'income' as defined in the 1941 Act (which is similar to the current definition of 'income', namely 'gross income' less exempt income). He was of the opinion that it was reasonable to accept that the legislature's intention was that a husband (later 'donor spouse') should pay tax on his wife's (later 'recipient spouse') profits or gains after deducting allowable expenditure (in other words 'taxable income') and not on her 'income' as defined. Based on the rule laid down in Halsbury, Laws of England, the court found that to use the literal (defined) meaning of 'income' would undermine the purpose of the section, since then the donor spouse would not be authorised to deduct expenditure incurred by the recipient spouse. Judge Watermeyer reasoned that, in practice, the donor spouse would surely be entitled to all the deductions which the recipient spouse would have been entitled to, had she been the taxpayer. Meyerowitz and Spiro (1995) agree with the view of the Simpson case, namely that 'income' in Section 7(2) refers to profits or gains, after deducting expenditure. De Koker and Williams (2015) also agree that 'income' in the context of Section 7(2) should not be interpreted as 'income' as defined in the Act.

Interestingly, Section 7(2B) of the Act, which addresses the issue of the expenditure, was only inserted in the Act by Income Tax Act 141 of 1992, and reads as follows:

So much of any deduction or allowance which may be made under the provisions of this Act in the determination of the taxable income derived from any income referred to in subsections (2) and (2A) as relates to any portion of such income which is under the provisions of that subsection deemed to be income accrued to a spouse shall be deemed to be a deduction or allowance which may be made in the determination of the taxable income of such spouse. (p. 9-10)

The authors of this article are of the opinion that it must have been the legislature's intention that Sections 7(2) and 7(2A) referred to 'income' as defined, or to 'gross income', otherwise Section 7(2B) would not have been added to specifically allow for the deduction of expenditure. Consequently, it is held that the interpretation of 'income' in the 1949 Simpson case, namely that Section 7(2) refers to 'taxable income', cannot be applied. Davis et al. (1999) also agree that it appears then that the Simpson case does not hold for Sections 7(2) and 7(2A). The predecessor of Section 7(2) arose in the 1914 Act and also referred to 'income', but the 1914 definition of 'income' was very different to the current definition. There was no distinction between 'income' and 'gross income' in
1914 and 'income' was defined as 'any gains or profits derived by, or accrued to or in favour of...'. Examples given in the 1914 definition included, inter alia, profit, gains, rents, interest and salaries, which seem to refer to gross amounts (in other words, before exemptions and deductions). Based on such an interpretation, it then makes sense that the legislature specifically added a provision to allow for the deduction of expenditure in 1992, and therefore, the authors of this article tend to lean towards an interpretation as 'gross income'. Interestingly, these profits and gains mentioned in the 1914 definition of 'income' were interpreted in the Simpson case as referring to net amounts, in other words, after exemptions and deductions. Such an interpretation, however, does not make sense to the authors of this article in the light of the fact that the legislature subsequently felt the need to add Section $7(2 B)$ to specifically deal with the deduction of expenditure.

\section{Section 7(3) of the Act}

Section 7(3) of the Act (Republic of South Africa 1962) reads as follows:

Income shall be deemed to have been received by the parent of any minor child or stepchild, if by reason of any donation, settlement or other disposition made by that parent of that child:

(a) it has been received by or has accrued to or in favour of that child or has been expended for the maintenance, education or benefit of that child; or

(b) it has been accumulated for the benefit of that child.

De Swardt et al. (2015) are of the opinion that the term 'income' used in Sections 7(2) to 7(7) should be interpreted as 'taxable income' (based on the judgement in the Simpson case) and that a provision similar to Section 7(8)(b) (which deals with the deduction of expenditure, as discussed under Section 7[8]) is therefore not necessary in these sections. Meyerowitz (2008) also considers 'income' in the context of Section 7(3), as well as in the context of all the other deeming provisions of Section 7, to mean 'taxable income', as it is unbelievable that the income is deemed to be that of the parent and the expenditure attached to the income, is left not to be deductible.

The purposive interpretation approach considers, inter alia, the evil which the legislature is intended to forbid and punish (Mota 2012). According to Olivier (1989), the purpose of Sections 7(3) to 7(6) is not to punish a taxpayer but to prevent tax avoidance. Any interpretation which will place the taxpayer in a worst position than what he would have been normally, therefore, seems to be contrary to the legislature's intention. So for instance, in this case, it would not make sense to be taxed on deemed income but not to be able to benefit from possible exemptions or deductions. Therefore, where no specific deductions provision exist in a section, it seems reasonable that the 'income' referred to in the section, should be interpreted as 'taxable income'. Alternatively, one can argue that no deductions are allowed, as no specific provision is made for it and therefore that 'income' cannot imply 'taxable income'. 
De Koker and Williams (2015) are of the opinion that, although no authority exists for it, for purposes of this section and Sections 7(4) to 7(7), 'income' should be interpreted as 'gross income' less related deductible expenses and losses. According to them, it would be unfair if the term 'income' is interpreted as defined, as a deduction for expenses incurred, will not be allowed. The authors of this article, therefore, agree that an interpretation that is more favourable to the taxpayer, namely 'taxable income', should be considered in the light of the contra fiscum rule. However, in the light of the fact that both Sections 7(2B) and $7(8)(b)$ specifically allow the deduction of expenses, it seems reasonable to the authors of this article to assume that such deductions are not allowed in the other subsections of Section 7. Therefore, it is submitted that the interpretation of 'income' as 'taxable income' in this context was not the legislature's intended meaning. If the term 'income' in the context of Section 7(3) is indeed interpreted in line with the view of De Koker and Williams (2015), namely as 'gross income' less related deductible expenses and losses, the question arises as to whether exempt income is simply ignored? In Section 7(7), the benefit of exempt income is specifically withheld from the taxpayer that is taxed on the deemed income; therefore, it is submitted by the authors of this article that one must assume that in the other subsections the taxpayer is entitled to that benefit. Otherwise, the legislature would have made specific mention of exempt income in all the other subsections and not merely in Section 7(7). If, however, no exempt income is applicable in a scenario and 'deductible' has the same meaning as 'allowable' deductions in terms of the Act, then the meaning of 'income' according to these authors, is similar to Meyerowitz and De Swardt et al.'s 'taxable income'. However, Davis et al. (1999) argued that, as the legislature provided specifically for net income (after deductions) to be attributed only under subsection (8), 'gross income' has to be attributed under the other subsections, which include Section 7(3).

According to Meyerowitz (2008), interpreting 'income' as 'taxable income' in Section 7 is also the view accepted by the South African Revenue Service (SARS). However, if that is the case, why is it not indicated as such in the Act or through guidance issued by the SARS and were provisions allowing the deduction of expenditure only added to Sections 7(2) and 7(8)? Therefore, the authors of this article do not agree with such an interpretation and are of the opinion that the meaning of 'income' in this subsection is intended to be 'income' as defined in Section 1 of the Act.

It is clearly evident that, based on the above-mentioned proposed interpretations, uncertainty exists with regard to the meaning of the term 'income' in this context, and different authors have different views. Similarly, uncertainty exists with regard to the meaning of the term 'income' throughout Sections 7(4) to 7(8), as illustrated below.

\section{Section 7(4) of the Act}

Section 7(4) of the Act (Republic of South Africa 1962) reads as follows:

Any income received by or accrued to or in favour of any minor child or stepchild of any person, by reason of any donation, settlement or other disposition made by any other person, shall be deemed to be the income of the parent of that child, if such parent or his or her spouse has made a donation, settlement or other disposition or given some other consideration in favour directly or indirectly of the said other person or his or her family. (Republic of South Africa, 1962:42)

The various authors ascribe a similar meaning to the term 'income' in Section 7(4) to that of Section 7(3) discussed above. These interpretations include 'taxable income', 'gross income' less related expenses and losses and 'gross income', while the authors of this article believe that it should be interpreted as 'income' as defined in Section 1 of the Act, as nothing indicates the contrary with reference to the interpretations discussed under Section 7(3).

\section{Section 7(5) of the Act}

Section 7(5) of the Act (Republic of South Africa 1962) reads as follows:

If any person has made any donation, settlement or other disposition which is subject to a stipulation or condition, whether made or imposed by such person or anybody else, to the effect that the beneficiaries thereof or some of them shall not receive the income or some portion of the income thereunder until the happening of some event, whether fixed or contingent, so much of any income as would, but for such stipulation or condition, in consequence of the donation, settlement or other disposition be received by or accrue to or in favour of the beneficiaries, shall, until the happening of that event or the death of that person, whichever first takes place, be deemed to be the income of that person. (Republic of South Africa, 1962:42-43)

The various authors' possible interpretations of the term 'income' discussed in Section 7(3), which also apply in the context of Section 7(5), include 'taxable income', 'gross income' less related expenses and losses and 'gross income'. They all seem to agree that 'income' in Section 7(5) is not meant to be interpreted as 'income' as defined. According to Clegg and Stretch (2015), problems can arise where, for example, a South African resident trust has been funded by a non-resident and the nature of the funding was gratuitous, when 'income' is interpreted as 'income' as defined. For instance, it is questionable, according to the author, whether the deemed 'income' amounts of the non-resident funder can nevertheless be exempt from tax, if they comply with the provisions of Section 10 that are applicable to non-residents. These authors further state that, for an interpretation of 'income' as 'taxable income' to hold (in other words, allowing non-resident exemptions), Section 7(5) should be interpreted as deeming the income to accrue to the non-resident. However, if 'income' is rather seen as having its defined meaning, then the assumption needs to be that the income, which essentially accrues to a resident, would be 
'income' (in other words, after Section 10 exemptions applicable to residents) of the resident and henceforth must be deemed 'income' of the non-resident. Clegg and Stretch (2015) submit all in all, although the matter cannot be beyond doubt, that the latter interpretation, namely 'income' as defined in the Act, is better, as that is also what they understand the view of the SARS to be. For the same reasons mentioned in the context of Section 7(3), the authors of this article also believe that the term 'income' in Section 7(4) should be interpreted as 'income' as defined in the Act.

\section{Section 7(6) of the Act}

Section 7(6) of the Act (Republic of South Africa 1962) reads as follows:

If any deed of donation, settlement or other disposition contains any stipulation that the right to receive any income thereby conferred may, under powers retained by the person by whom that right is conferred, be revoked or conferred upon another, so much of any income as in consequence of the donation, settlement or other disposition is received by or accrues to or in favour of the person on whom that right is conferred, shall be deemed to be the income of the person by whom it is conferred, so long as he retains those powers. (Republic of South Africa, 1962:43)

Interpretations of the term 'income' in Section 7(6) are similar to those discussed for Section 7(3). These interpretations include 'gross income' less related deductible expenses and losses, and 'taxable income', while Davis et al. (1999), however, interpret it as 'gross income'. The authors of this article agree that a gross amount, before deductions and exemptions, is implied in this context, based on the phrase 'the right to receive any income'. This leads the authors of this article to believe that a taxpayer is in fact entitled to income exemptions in the other subsections of Section 7 in which the wording does not specifically refer to gross amounts, such as here.

\section{Section 7(7) of the Act}

Section 7(7) of the Act (Republic of South Africa 1962) reads as follows:

If by reason of any donation, settlement or other disposition made, whether before or after the commencement of this Act, by any person (hereinafter referred to as the donor):

(a) the donor's right to receive or have paid to him or for his benefit any amount by way of rent, dividend, foreign dividend, interest, royalty or similar income in respect of any movable or immovable property (including without limiting the foregoing any lease, company share, marketable security, deposit, loan, copyright, design or trade mark) or in respect of the use of, or the granting of permission to use, such property, is ceded or otherwise made over to any other person or to a third party for that other person's benefit in such manner that the donor remains the owner of or retains an interest in the said property or if the said property or interest is transferred, delivered or made over to the said other person or to a third party for the said other person's benefit, in such manner that the donor is or will at a fixed or determinable time be entitled to regain ownership of or the interest in the said property; or (b) the donor's right to receive or have paid to him or for his benefit any income that is or may become due to him by any other person acting in a fiduciary capacity is ceded or otherwise made over to any other person or to a third party for that other person's benefit in such manner that the donor is or will at a determinable time be entitled to regain the said right,

any such rent, dividend, foreign dividend, interest, royalty or income (including any amount which, but for this subsection, would have been exempt from tax in the hands of the said other person) as is received by or accrues to or for the benefit of the said other person on or after 1 July 1983 and which would otherwise, but for the said donation, settlement or other disposition, have been received by or have accrued to or for the benefit of the donor, shall be deemed to have been received by or to have accrued to the donor.

The various interpretations of the term 'income' that were already discussed for Section 7(3) apply similarly to Section 7(7) and include those of De Koker and Williams (2015), namely 'gross income' less related deductible expenses and losses, in contrast with Meyerowitz's (2008) and De Swardt et al.'s (2015) opinion that 'income' should rather be interpreted as 'taxable income'. The authors of this article, however, agree with Davis et al. (1999) that the meaning of 'income' in this context can be interpreted as 'gross income'. This is deduced from the wording in the last sentence of Section 7(7), which includes otherwise exempt income in the 'income' that the taxpayer is deemed to have received. Once again this leads the authors of this article to believe that a taxpayer is entitled to income exemptions in the subsections of Section 7 where the wording does not specifically disregard exemptions as in Section 7(7).

\section{Section 7(8) of the Act}

Section 7(8) of the Act (Republic of South Africa 1962) reads as follows:

(a) Where by reason of or in consequence of any donation, settlement or other disposition (other than a donation, settlement or other disposition to an entity which is not a resident and which is similar to a public benefit organisation contemplated in section 30) made by any resident, any amount is received by or accrued to any person who is not a resident (other than a controlled foreign company in relation to such resident), which would have constituted income had that person been a resident, there shall be included in the income of that resident so much of that amount as is attributable to that donation, settlement or other disposition.

(b) So much of any expenditure, allowance or loss incurred by the person contemplated in paragraph:

(a) as does not exceed the amount included in the income of the resident in terms of that paragraph and which would be allowable as a deduction under this Act in the determination of the taxable income derived from that amount had that person been a resident, is deemed to be an expenditure, allowance or loss incurred by that resident for purposes of the determination of the taxable income of that resident from that amount.

What makes this subsection different from subsections 7 (3) to 7(7) is the existence of Section 7(8)(b), included in 2005, which 
specifically allows the deduction of certain expenditure, allowances or losses relating to the deemed income (Republic of South Africa 2005a). This is similar to Section 7(2B).

Clegg and Stretch (2015) state that 'income' in the context of Section 7(8) should be interpreted as 'income' as defined in the Act. However, when interpreting the meaning in the context of Section 7(8), one should consider the amendment of Section 7(8) to refer to 'any amount' instead of to 'income' (Republic of South Africa 2004a). The reason for the amendment was that it might have been argued that the term 'income' in the previous version of Section 7(8), only referred to income from a South African source and that foreign-sourced income of a nonresident technically fell outside the ambit of Section 7(8) (Republic of South Africa 2004b). The amendment therefore ensures that all the receipts and accruals of a non-resident are deemed to be income of the resident, if they would have constituted income had they been received by or accrued to a resident (Republic of South Africa 2005b). Once Section 7(8)(b) was subsequently added, the resident is now allowed to deduct allowable expenses too. According to Clegg and Stretch (2015), until this amendment, it was considered that 'income' in this context should have been interpreted as a net amount, calculated in a similar manner as 'taxable income', based on only income from a South African source. Meyerowitz's (2008) interpretation of 'income' as 'taxable income' agrees to some extent to that of Clegg and Stretch, although he does not address the effect of the amendment on his interpretation. De Swardt et al. (2015) and De Koker and Williams (2015) are of the opinion that 'income' in this context should be interpreted as 'income' as defined. The authors of this article believe that the legislature intended for 'income' in the context of Section $7(8)$ to be interpreted either as 'gross income' or 'income' as defined, otherwise they would not have specifically provided for the deductibility of expenditure. In Section 7(7) the benefit of exempt income is specifically withheld from the taxpayer that is taxed on the deemed income, and in Section 7(6) the wording specifically refers to gross amounts being taxable as deemed income. Therefore, it is submitted by the authors of this article that one must assume that in the other subsections where the wording is silent regarding exemptions, the taxpayer is entitled to potential income exemptions. Consequently, the authors of this article agree with De Swardt et al. (2015) and De Koker and Williams (2015) that 'income' in the context of Section 7(8) should be interpreted as 'income' as defined.

\section{Basic illustration of effect of different interpretations on a taxpayer's taxable income}

An example of the impact of each possible interpretation, as discussed in the section 'Understanding the meaning of "income" in Sections 7(2) to 7(8) of the Act' of this article, is now provided to illustrate the effect of possible incorrect interpretations of the term 'income' in Sections 7(2) to 7(8) of the Act.

Assume that taxpayer $\mathrm{X}$ is deemed, by any one of Sections $7(2)$ to $7(8)$, to be taxable on certain 'income' received by or
TABLE 1: Receipts or accruals and related expenditure.

\begin{tabular}{lc}
\hline Description & Rand \\
\hline $\begin{array}{l}\text { Gross earnings or receipts or proceeds (assume that this full } \\
\text { amount also meets the definition of 'gross income' in the Act) }\end{array}$ & $\mathbf{1 0 0 0 0 0}$ \\
$\begin{array}{l}\text { - Portion that is exempt from tax } \\
\text { - Portion that is taxable }\end{array}$ & 10000 \\
$\begin{array}{l}\text { Related expenditure incurred } \\
\text { - Portion that would have been deductible for tax purposes by } \\
\text { person A, should he have been taxed on the income }\end{array}$ & $\mathbf{2 0 0 0 0}$ \\
- Non-deductible portion & 15000 \\
\hline \begin{tabular}{l} 
Net profit before tax \\
\hline
\end{tabular} & 5000 \\
\hline
\end{tabular}

TABLE 2: Possible amounts to be included in taxpayer's tax return. Description

'Gross income' or amount 100000

Section 1 definition ('gross income' less exempt income)

'Taxable income' ('income' less allowable expenditure) or profits or gainst

'Gross income' less related deductible expenditure

$\dagger$, Based on the Simpson case, these are interpreted as being the same.

accrued to person A. A breakdown of amounts received by or accrued to person A by reason of a donation, settlement or other disposition by taxpayer $\mathrm{X}$, together with related expenditure incurred by person $\mathrm{A}$, is as in Table 1 (in rand).

Table 2 illustrates the amounts that would be included in taxpayer X's income in his income tax return, based on each of the possible interpretations of 'income' in Section 7.

This example clearly illustrates the significant impact that the interpretation of the term 'income' in Sections 7(2) to 7(8) can have on a taxpayer's 'taxable income' and for which a suitable solution is required to ensure consistency.

\section{Conclusion and recommendations}

In terms of the literal approach of interpretation, unless the context otherwise indicates, the term 'income' in Sections 7(2) to 7(8) of the Act should be ascribed its ordinary meaning, as defined in Section 1 of the Act. Based on the study performed, however, the context of Sections 7(2) to 7(8) of the Act sometimes indicates a different meaning. The purposive approach was therefore followed to determine the meaning of the term 'income' that is used in Sections 7(2) to 7(8) of the Act. Interestingly, it was established that different authors interpret the meaning of the term 'income' differently, and the interpretations also differ among the various subsections of Section 7. The authors of this article believe that the legislature's intention, albeit possibly unfair in terms of not allowing deductions or exemptions throughout Section 7 , was for the term 'income' to be interpreted as 'gross income' in Sections 7(2), 7(6) and 7(7) and as 'income' in Sections 7(3), $7(4), 7(5)$ and 7(8).

The meaning of the term 'income' for purposes of Sections 7(2) to $7(8)$ of the Act can be widely argued and remains an uncertainty. It is therefore imperative that application guidance is issued or that the wording in Sections 7(2) to 7(8) be amended to reflect the intended meaning of the legislature, where it is not meant to be 'income' as defined in Section 1 of the Act. 


\section{Acknowledgements Competing interests}

The authors declare that they have no financial or personal relationship(s) that may have inappropriately influenced them in writing this article.

\section{Authors' contributions}

Both the authors have contributed equally.

\section{References}

Cape Brandy Syndicate V Inland Revenue Commissioners: CA 1921 [1 KB 64].

Clegg, D. \& Stretch, R., 2007, Income Tax in South Africa, Electronic edition updated: September 2015, LexisNexis, viewed 18 November 2015, from http://www. mylexisnexis.co.za.ez.sun.ac.za/Index.aspx

Commissioner for Inland Revenue V Simpson [1949] 4 All SA 460(A).

Davis, D.M., Olivier, L. \& Urquhart, G.A., 1999, Juta's income tax, Juta \& Co, Claremont, CA.

De Koker, A.P. \& Williams, R.C. 2001, Silke on South African Income Tax, Electronic edition updated: September 2015. LexisNexis, viewed 19 November 2015, from http://www.mylexisnexis.co.za.ez.sun.ac.za/Index.aspx

De Swardt, R.D., Koekemoer, A.D., Stiglingh, M., Van Zyl, L. \& Wilcocks, J.S., 2015, SILKE: Suid-Afrikaanse Inkomstebelasting 2015, Lexis Nexis, Durban.

Goldswain, G.K., 2008, 'The purposive approach to the interpretation of fiscal legislation: The winds of change', Meditari Accounting Research 16(2), 107-121. https://doi.org/10.1108/10222529200800015

Hutchinson, T. \& Duncan, N., 2012, 'Defining and describing what we do: Doctrinal legal research', Deakin Law Review 17(1), 83-119. https://doi.org/10.21153/ dlr2012vol17no1art70

IFRS Foundation, 2015, A guide through International Financial Reporting Standards, Part A1, IFRS Foundation, London.

Meyerowitz, D., 2008, Meyerowitz on income tax (2007-2008), The Taxpayer, Cape Town.

Meyerowitz, D. \& Spiro, E., 1995, Meyerowitz and Spiro on income tax, The Taxpayer, Cape Town.

Mota, M.M., 2012, The meaning of 'actually incurred' in section 11 of the income tax act in the context of three specific transactions, Master thesis, University of Pretoria, Pretoria.
Olivier, P.A., 1989, Trustreg en praktyk, De Jager-Haum Uitgewers, Pretoria-Wes.

R Koster \& Son (Pty) Ltd \& Another V Commissioner for Inland Revenue [1985] 47 SATC 23.

Republic of South Africa, 1914, Income Tax Act 28 of 1914, Government Printer Pretoria.

Republic of South Africa, 1925, Income Tax Act 40 of 1925, Government Printer, Pretoria.

Republic of South Africa, 1932, Income Tax Act 28 of 1932, Government Printer Pretoria.

Republic of South Africa, 1941, Income Tax Act 31 of 1941, Government Printer Pretoria.

Republic of South Africa, 1962, Income Tax Act 58 of 1962, Government Printer, Pretoria.

Republic of South Africa, 1983, Explanatory Memorandum on the Income Tax Bill 1983, Government Printer, Pretoria.

Republic of South Africa, 1991, Explanatory Memorandum on the Income Tax Bill 1991, Government Printer, Pretoria.

Republic of South Africa, 1992, Income Tax Act 141 of 1992, Government Printer, Pretoria.

Republic of South Africa, 1996, Constitution of the Republic of South Africa Act, No 108 of 1996, Government Printer, Pretoria.

Republic of South Africa, 2000, Explanatory Memorandum on the Revenue Laws Amendment Bill 2000, Government Printer, Pretoria.

Republic of South Africa, 2004a, Revenue Laws Amendment Act 32 of 2004 Government Printer, Pretoria.

Republic of South Africa, 2004b, Explanatory Memorandum on the Revenue Laws Amendment Bill 2004, Government Printer, Pretoria.

Republic of South Africa, 2005a, Revenue Laws Amendment Act 31 of 2005, Government Printer, Pretoria.

Republic of South Africa, 2005b, Explanatory Memorandum on the Revenue Laws Amendment Bill 2005, Government Printer, Pretoria.

The Chambers Dictionary, 2015, viewed 14 January 2016, from http://www. credoreference.com/

The Collins English Dictionary, 2015, viewed 14 January 2016, from http://www. credoreference.com

The Oxford English Dictionary, 2015, viewed 14 January 2016, from http://www.oed. $\mathrm{com} /$

The Penguin English Dictionary, 2015, viewed 14 January 2016, from http://www. credoreference.com

Van der Zwan, P., 2015, 'Interpretation of tax law', Accountancy SA 22-23. 